\title{
China-ASEAN Trade Relations: A Study of Determinants and Potentials
}

\author{
Hiep Xuan TRAN ${ }^{1}$, Nhan Thanh Thi HOANG ${ }^{2}$, Anh Thuy NGUYEN ${ }^{3}$, Hoan Quang TRUONG ${ }^{4}$, Chung Van DONG
}

Received: June 25, 2020 Revised: July 05, 2020 Accepted: August 10, 2020

\begin{abstract}
The purpose of this study is to investigate the development and determinants of China-ASEAN trade relations over the period of $2000-2018$. Employing both the qualitative and quantitative approaches, the results show that the trade relations between China and the Association of South East Asian Nations (ASEAN) have remarkably developed and rapidly grown over times, with a significantly important concentration on the segments of high technological and medium technological products. We also find that China's economic scale is crucially impacting on the China-ASEAN trade relations under both the aggregate and sub-sector level. It is interesting to notice that there is no evidence to support accession to the World Trade Organization (WTO) and officially forming of ASEAN-China Free Trade Agreement (ACFTA) to enhance trade relation between both sides. The findings also quantitatively indicate that there is much significant potential for the expansion of mutual trade between China and some members of ASEAN such as Brunei, Laos and Malaysia, while less potential is predicted for other members of ASEAN. It is strongly suggested that China and ASEAN should find a new proactive approach and make more efforts in improving the mutual political trusts to enhance trading activities in the coming years.
\end{abstract}

Keywords: China-ASEAN, Trade Structure, Technological Content, Trade Potential

JEL Classification Code: F10, F12, F13, F14, F17

\section{Introduction}

Following the implementation of the reform and openingup policy in 1978, China has achieved very high economic growth for next four decades with sharp changes in terms of economic size, economic structure, and China's position in the global economy (Ju \& Yu, 2018). Meanwhile, ASEAN was established back in 1967, but it has been recently considered an emerging economic bloc in the region (Truong et al., 2019a; 2019b). Following the establishment of strategic partnership

${ }^{1}$ First Author. Institute of Socio-Economic Research, Duy Tan University, Da Nang, Vietnam. Email: tranxuanhiep@dtu.edu.vn 2Dong Do University, Hanoi, Vietnam. Email: nhanth_iwep@yahoo.com ${ }^{3}$ Faculty of Political Economy, VNU University of Economics and Business, Hanoi, Vietnam. Email: maichithuyanh@gmail.com ${ }^{4}$ Institute for Southeast Asian Studies, Vietnam Academy of Social Sciences, Hanoi, Vietnam. Email: quanghoan2310@gmail.com ${ }^{5}$ Corresponding Author. Institute of World Economics and Politics, Vietnam Academy of Social Sciences, Vietnam [Postal Address: 1 Lieu Giai, Ba Dinh, Hanoi, 10000, Vietnam] Email: chungdv.iwep@vass.gov.vn

(c) Copyright: The Author(s)

This is an Open Access article distributed under the terms of the Creative Commons Attribution Non-Commercial License (https://creativecommons.org/licenses/by-nc/4.0/) which permits unrestricted non-commercial use, distribution, and reproduction in any medium, provided the original work is properly cited. in 1991, a changing regional and global context has provided opportunities for China and ASEAN countries to forge closer relations. These include the constructive role played by the government of China in dealing with the Asian financial crisis coupled with changing U.S. priorities in Asia during the late 1990s, China's accession to WTO in 2001, the full establishment of the ACFTA in 2010, and the forming of ASEAN Economic Community (AEC) at the end of 2015 (Santasombat, 2018). Especially, in 2013 China launched its Belt and Road Initiative (BRI), including the Maritime Silk Road and the Silk Road Economic Belt, aiming to boost China's global trade by building rail and sea links connecting it with Southeast Asia and Europe (Balandchard, 2018). Besides the BRI, the Asian Infrastructure Investment Bank (AIIB) - a China-led initiative officially launched in 2014, aiming to improve connectivity between the countries in the Asian region via funding of vast infrastructure projects (Chen, 2018). The two sides' cooperation also takes place in other frameworks such as "ASEAN plus three" (ASEAN and its three partners, China, Japan and South Korea), and the Regional Comprehensive Economic Partnership-RCEP (currently including ASEAN, China, Japan, South Korea, Australia and New Zealand).

Obviously, the reciprocal trade flow is one of the most notable successes in the development of China-ASEAN 
economic relations. The figures from United Nations Conference on Trade and Development (UNCTAD) show that the mutual trade activities had reached a peak of US\$497.6 billion in 2018 from only US\$39.7 billion in 2000 . Consequently, not only China, but also ASEAN as a bloc and each member of ASEAN as well have turned into the crucially significant counterparts to each other, somehow much more important in favor of ASEAN. This study seeks responses to two question: What are factors influencing China-ASEAN trade, under both aggregate trade and technological content? Is there much room for trade expansion between China and ASEAN countries?

The existing literature includes much research on mutual trade flows among partners or between regions. With a rapid economic growth and playing an increasingly vital role in the international trade, it is no doubt that the East Asian region has been the object of attention of scholars (Gaulier et al., 2007; Athukorala, 2011; Armstrong, 2015; Truong et al., 2019a, 2019b). One of the most common findings from the literature is that manufacturing sectors have mainly traded and occupied a largest share in total trade flows in the region. The major role comes from global companies in Japan, right after China, and followed by South Korea. Going in line with this trend, members of ASEAN bloc have joined and penetrated more deeply economic networks regionally and internationally, especially taking a vital role in the global value chain. It is not surprising that China-ASEAN trade relations have been the center of attention by not only policy-makers of both sides, but also international scholars. We might list here a range of influential works by Wong and Chan (2003), Men (2007), Devadason (2010), Chin and Stubbs (2011), Chakraborty and Kumar (2012), Liqin (2012), Tai and Soong (2014), Tham et al. (2016), Hye et at. (2016), Rao and Pathak (2016), Chiang (2019), He and Wang, (2019), and Oktora and Firdani (2019).

An in-depth review on the literature reveals an academic gap. Even though the reciprocal trade relation between China and ASEAN has been examined, most have been done through qualitative approaches such of descriptive statistics or comparative studies. There is a huge lack of empirical evidence on the determinants of China-ASEAN trade under both aggregate trade and sub-sector trade analyzed with quantitative methods such as econometrics. By applying the gravity model with a PPML (Poisson pseudo-maximum-likelihood) estimator proposed by Santos Silva and Tenreyro (2006, 2011), our current paper will investigate the factors influencing trade activities between China and ASEAN as a whole and sub-sectors, i.e., technological content over the period 2000 to 2018 . We also provide a prediction of trade potential between China and ASEAN to help readers and policy-makers have a broader view in the years ahead.

The remainder of present paper is structured as follows. Section 2 considers trade performance and trade structure. Section 3 looks in details at the determinants of ChinaASEAN trade. Section 4 explores the trade potential. Section 5 provides concluding remarks.

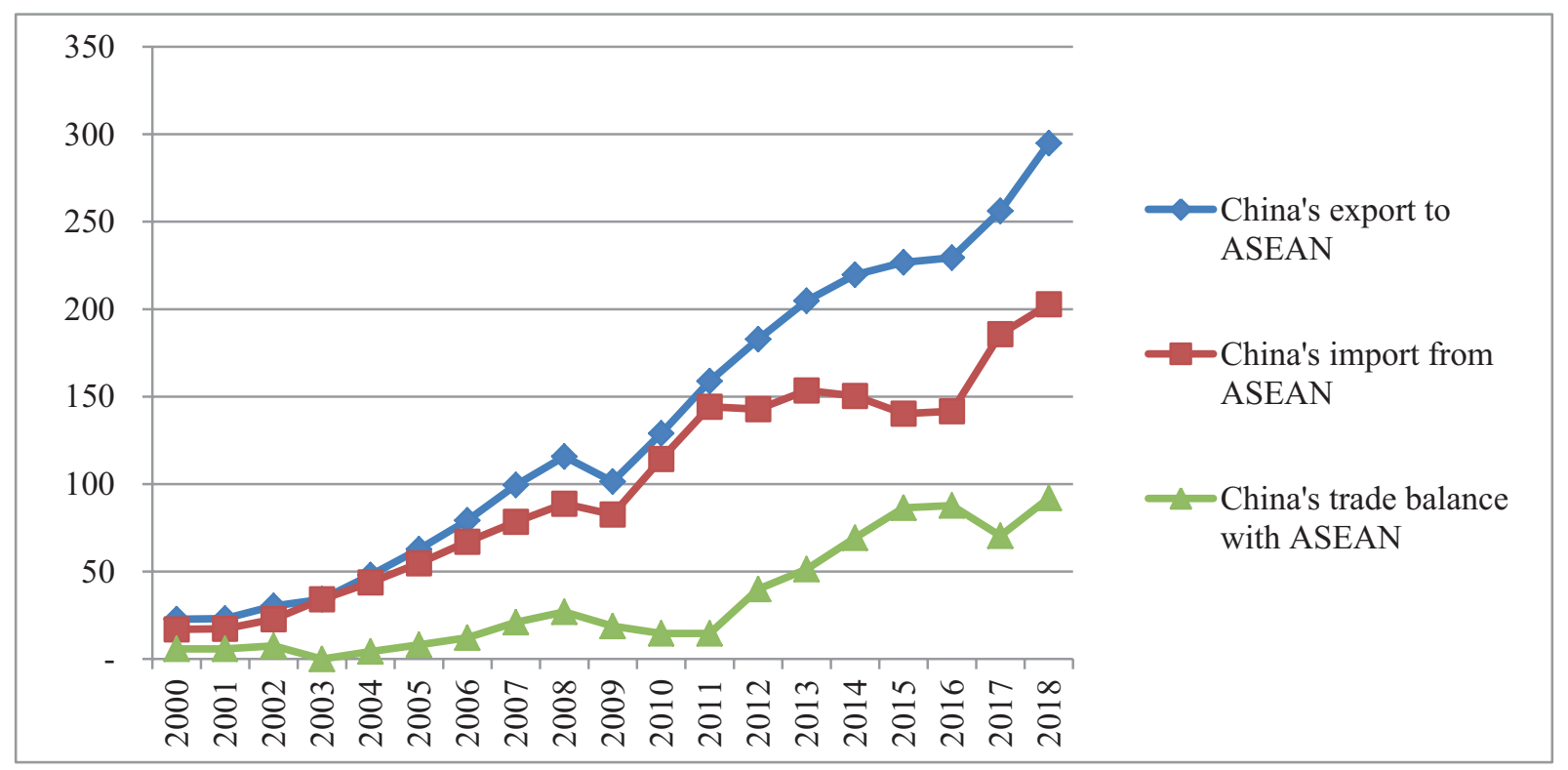

Source: Author's combination and calculation using data from UNCTAD.

Figure 1: Bilateral Trade in Goods between China and ASEAN (US\$ billion) 


\section{Main Characteristics of China-ASEAN Trade Relations}

Retrieved from the database of UNCTAD, Figure 1 compiles and visualizes the trade performance between China and ASEAN for period 2000 to 2018. Total trade and separate components of trade have been grown widely for both sides. In particular, the total exports by China to members of ASEAN jumped to US $\$ 294.8$ billion in 2018 , from US\$22.7 billion in 2000 and US\$129.0 in 2010. This means that within less that 20 years, China's exports to ASEAN increased thirteen-folds. Total imports to China from southeast Asian countries grew dramatically, recording US\$202.7 billion in 2018, compared to US\$16.9 billion in 2000, US\$54.7 billion in 2005 and US\$114.4 billion in 2010. The balance of trade is in China's favor. Computation from data of UNCTAD reports that trade surplus is worsening in ASEAN, climbing up US\$92.0 billion in 2018, growing roughly fifteen-fold compared with the figure of US\$5.7 billion in 2000. It is worth noting that China's trade surplus with ASEAN expanded very rapidly after the full establishment of the ACFTA in 2010, suggesting that signing the ACFTA was much better for China than ASEAN members (see Figure 1).

On an important level, processed data from UNCTAD show that in 2018 the share of trade, exports and imports with China on ASEAN's trade, exports and imports with the world reached $17.25 \%, 13.94 \%$ and $20.58 \%$, respectively. China has been ASEAN's top trading partner for 10 consecutive years. In the opposite direction, ASEAN is China's third largest trading partner, after the European Union (EU) and the USA, for eight years in a row. More specifically, in 2018 China was the largest source of imports for nine out of the 10 ASEAN economies (Cook, 2019). In the same year, China was the largest national export market for four ASEAN member states, namely, Indonesia, Myanmar, Singapore and Thailand; and the second largest for three of them, namely,
Laos, Malaysia (after Singapore) and Vietnam (after the USA). Meanwhile, China was the third largest national export market for the Philippines, the fifth largest for Cambodia, and only the eighth largest for Brunei (Cook, 2019). In terms of market distribution, Table 1 shows that trade exchange between China and ASEAN principally focused on the largest member economies, namely, Singapore, Malaysia, Indonesia, Thailand, and Vietnam, while the trade volume between China and Brunei, Myanmar, Laos and Cambodia was very low.

Going into the nature of trade, by using data from UNCTAD, Table 2 illustrates that the exports and imports between China and ASEAN consist of technological content. In terms of exports, Table 2 indicates that over the 20002018 period, China's exports to ASEAN market had focused mainly on high technology and medium technology products, with the total share of the two sub-sectors accounting for about $60 \%$. The next important sub-sector is low technology manufactured products, accounting for one-fifth of China's total exports to ASEAN in 2018. On the other hand, the share of primary goods remained very low after 2005 .

In terms of imports, Table 1 illustrates that China's imports from ASEAN countries also concentrated on high technology products, accounting for about $30 \%$. It is followed by resource-based product group that consisting of one-fourth of China's total imports. The share of primary products in China's imports from ASEAN declined over years, reaching $17 \%$ in 2018 , while the share of low technology manufactured goods remained unchanged between 2000 and 2018, sharing $18 \%$. All in all, the nature of the trade between China and ASEAN significantly focused on high technology and medium technology products, particularly in China's export. This to some degree reveals the improvement of production capability in China and ASEAN countries as the high technology products often contain higher added value comparing to those with the low technology content (Truong et al., 2019b; Wong \& Chan, 2003).

Table 1: China's export to ASEAN by technological content (\%)

\begin{tabular}{|l|c|c|c|c|c|c|c|c|c|c|}
\hline Technological content & \multicolumn{2}{|c|}{$\mathbf{2 0 0 0}$} & \multicolumn{2}{|c|}{$\mathbf{2 0 0 5}$} & \multicolumn{2}{c|}{2010} & \multicolumn{2}{c|}{2015} & \multicolumn{2}{c|}{2018} \\
\hline & export & import & export & import & export & import & export & import & export & import \\
\hline Primary goods & 12.56 & 24.91 & 6.46 & 17.96 & 5.32 & 17.31 & 4.74 & 16.60 & 4.88 & 17.65 \\
\hline Resource-based manufactures & 12.03 & 22.05 & 11.63 & 16.43 & 12.24 & 24.57 & 9.82 & 22.97 & 11.73 & 24.24 \\
\hline Low-technology manufactures & 16.83 & 3.94 & 15.07 & 4.13 & 18.23 & 4.12 & 22.20 & 6.30 & 21.25 & 7.13 \\
\hline $\begin{array}{l}\text { Medium-technology } \\
\text { manufactures }\end{array}$ & 26.69 & 18.58 & 23.40 & 18.01 & 27.80 & 16.39 & 30.91 & 18.73 & 29.10 & 18.86 \\
\hline High-technology manufactures & 31.29 & 29.32 & 37.66 & 33.78 & 35.62 & 35.05 & 31.71 & 32.44 & 32.62 & 30.26 \\
\hline Unclassified products & 0.60 & 1.20 & 5.78 & 9.68 & 0.79 & 2.55 & 0.62 & 2.96 & 0.43 & 1.85 \\
\hline Total & 100 & 100 & 100 & 100 & 100 & 100 & 100 & 100 & 100 & 100 \\
\hline
\end{tabular}

Source: Author's combination and calculation using data from UNCTAD. 


\section{Determinants of China-ASEAN Trade}

\subsection{Econometric Specification}

As known widely, the gravity model was first used by Tinbergen (1962) to consider the influence of geographical distance and economic size on international bilateral trade. Then, the model becomes one of the most popular approaches in exploring the determinants of international trade. The gravity model is shown as follows:

$$
\operatorname{trade}_{i j t}=g \frac{M_{i t} M_{j t}}{D_{i j}}
$$

where, Trade $e_{i j}$ is trade value between targeted country $\mathrm{i}$ and destinated country $\mathrm{j}$ in year $\mathrm{t} ; \mathrm{M}_{\mathrm{i}}, \mathrm{M}_{\mathrm{i}}$ present economic masses; $\mathrm{D}_{\mathrm{ij}}$ is distance, and $\mathrm{g}$ is the gravitational term. It is straightforward to find that the equation (1) can be expressed in a linear form as following:

$$
\operatorname{lntrade}_{\mathrm{ijt}}=\operatorname{lng}+\ln M_{\mathrm{it}}+\ln M_{\mathrm{jt}}+\ln D_{\mathrm{ij}}+\sigma_{\mathrm{ijt}}
$$

To investigate influencing factors on bilateral trade between China and ASEAN countries, we apply a gravity variation proposed by Anderson and Wincoop (2003), which is presented as follows:

$$
\begin{aligned}
\text { lntrade }_{\mathrm{ij}}= & \beta_{0}+\beta_{1} \ln M_{i t}+\beta_{2} \ln M_{j t}+\beta_{3} \ln D_{i j} \\
& +\beta_{4} R_{i j t}+\beta_{5} \gamma_{i j t}+\sigma_{i j t}
\end{aligned}
$$

where $\mathrm{R}$ is a set of multilateral resistances, $\gamma$ is a vector of gravity dummies, and $\sigma$ is error term.

Admittedly, influencing factors on trade flows are different from each component, which may affect positively exports, but negatively import, and vice versa. Thus, we will estimate determinants of trade flows between China and ASEAN for imports and exports separately, which is exhibited in specific form as follows:

$$
\begin{aligned}
\text { lntrade }_{i j t}= & \beta_{0}+\beta_{1} \ln \left(\text { gdp }_{i t} g d p_{j t}\right)+\beta_{2} \ln \left(\text { income }_{i t} \text { income }_{j t}\right) \\
& +\beta_{3} \ln D_{i j}+\beta_{4} \sum R_{i j t}+\beta_{5} \sum \gamma_{i j t}+\sigma_{i j t}
\end{aligned}
$$

$$
\begin{aligned}
\operatorname{lnexport}_{i j t}= & \beta_{0}+\beta_{1} \ln \left(g d p_{i t} g d p_{j t}\right)+\beta_{2} \ln \left(\text { income }_{i t} \text { income }_{j t}\right) \\
& +\beta_{3} \ln D_{i j}+\beta_{4} \sum R_{i j t}+\beta_{5} \sum \gamma_{i j t}+\sigma_{i j t}
\end{aligned}
$$

lnimport $_{i j t}=\beta_{0}+\beta_{1} \ln \left(\right.$ gdp $\left._{i t} g d p_{j t}\right)+\beta_{2} \ln$ income $_{i t}$ income $\left._{j t}\right)$

$$
+\beta_{3} \ln D_{i j}+\beta_{4} \sum R_{i j t}+\beta_{5} \sum \gamma_{i j t}+\sigma_{i j t}
$$

where, gdp denotes gross domestic products of China (i) and members of ASEAN (j) in year t; D is geographical distance between parties; $\mathrm{R}$ is a set of trading multilateral resistances including official member of the WTO (wto), the ACFTA (acfta), and joining BRI (obor); $\gamma$ is a vector of gravity dummies consisting of sharing border (border), landlocked country (landlocked) and common language (language); and $\sigma$ is error term.

\subsection{Estimation Issues}

It is important to realize that there are various elements that affect bilateral trade among countries. Thus, it is unavoidable there exists unobserved heterogeneity in estimating determinant variables (Gujarati, 2004). To reduce this problem, we use panel data for regression. Additionally, panel data also works well in investigating undetectably specific factors (Egger, 2002). In the literature, working with panel data, there are three techniques used for estimation - pool, fixed effects and random effects approaches. However, all three approaches cannot deal with a case of multiplicative model or a case of zero trade. As a result, these methods might possibly turn out with biases. In order to remedy this problematic issue, we employ the so-called PPML estimator, introduced by Santos-Silva and Tenreyro (2006). With strong theoretical foundation and significant empirical evidence, PPML approach has been considered as one of the most efficient techniques for estimating gravity equation (2011). Then, the estimation equation system (4) can be rewritten as follows:

$$
\begin{aligned}
\text { trade }_{i j t}= & \beta_{0}+\beta_{1} \ln \left(\text { gdp }_{i t} g d p_{j t}\right) \\
& +\beta_{2} \ln \left(\text { income }_{i t} \text { income }_{j t}\right) \\
& +\beta_{3} \ln D_{i j}+\beta_{4} \sum R_{i j t}+\beta_{5} \sum \gamma_{i j t}+\sigma_{i j t} \\
\text { export }_{i j t}= & \beta_{0}+\beta_{1} \ln \left(\text { gdp }_{i t} g d p_{j t}\right) \\
& +\beta_{2} \ln \left(\text { income }_{i t} \text { income }_{j t}\right) \\
& +\beta_{3} \ln D_{i j}+\beta_{4} \sum R_{i j t}+\beta_{5} \sum \gamma_{i j t}+\sigma_{i j t} \\
\text { import }_{i j t}= & \beta_{0}+\beta_{1} \ln \left(\text { gdp }_{i t} g d p_{j t}\right) \\
& +\beta_{2} \ln \left(\text { income }_{i t} \text { income }_{j t}\right) \\
& +\beta_{3} \ln D_{i j}+\beta_{4} \sum R_{i j t}+\beta_{5} \sum \gamma_{i j t}+\sigma_{i j t}
\end{aligned}
$$

To check the appropriateness of PPML estimator, heteroscedasticity-robust Reset Test-Ramsey test was also performed as further empirical evidence. For the purpose of providing a broader picture and comparing with the PPML estimator, we operate the estimation with random effects approach as well. 
Table 2: Descriptive Statistics

\begin{tabular}{|c|c|c|c|c|c|}
\hline Variable & Obs & Mean & Std. Dev. & Min & Max \\
\hline trade & 190 & 23117 & 28341.8 & 32.8972 & 109184 \\
\hline export & 190 & 13209.6 & 16069.3 & 26.9919 & 67150.9 \\
\hline primary & 190 & 712.514 & 841.971 & 0.27964 & 3485.55 \\
\hline resource-based & 190 & 1386.39 & 1693.51 & 1.10678 & 7793.95 \\
\hline low technology & 190 & 2640.28 & 3324.84 & 1.90544 & 17763.1 \\
\hline medium technology & 190 & 3782.89 & 4693.69 & 3.40978 & 20305.9 \\
\hline high technology & 190 & 4474.48 & 6053.34 & 0.91539 & 28107.2 \\
\hline unclassified & 190 & 145.2 & 417.1 & 0.0003 & 4021.71 \\
\hline import & 190 & 9907.41 & 12799 & 5.90534 & 52507.8 \\
\hline primary & 190 & 1759.74 & 2358.13 & 2.14868 & 11383.9 \\
\hline resource-based & 189 & 2398.94 & 3231.36 & 0.00027 & 13378.9 \\
\hline low technology & 190 & 518.71 & 933.064 & 0.00002 & 6938.05 \\
\hline medium technology & 190 & 1768.04 & 3155.69 & 0.00171 & 16722.9 \\
\hline high technology & 190 & 3199.79 & 5206.1 & 0 & 21027.7 \\
\hline unclassified & 190 & 274.564 & 992.761 & 0 & 7881.19 \\
\hline gdpi & 190 & 6105.6 & 4125.87 & 1211.35 & 13608.2 \\
\hline gdpj & 190 & 171.211 & 212.458 & 1.7312 & 1042.17 \\
\hline incomei & 190 & 4507.11 & 2956.42 & 959.373 & 9770.85 \\
\hline incomej & 190 & 9401.22 & 15152.9 & 137.168 & 64581.9 \\
\hline distance & 190 & 2913.7 & 829.726 & 1744 & 4198 \\
\hline language & 190 & 0.2 & 0.40106 & 0 & 1 \\
\hline landlocked & 190 & 0.1 & 0.30079 & 0 & 1 \\
\hline border & 190 & 0.3 & 0.45947 & 0 & 1 \\
\hline obor & 190 & 0.31579 & 0.46606 & 0 & 1 \\
\hline wto & 190 & 0.83684 & 0.37049 & 0 & 1 \\
\hline acfta & 190 & 0.47368 & 0.50063 & 0 & 1 \\
\hline
\end{tabular}

\subsection{Data Analysis}

Data and all relevant variables are gathered in a panel set including trade flows of exports and imports, gross domestic, geographical distance, gravity factors, and trading multilateral resistances over the period 2000-2018 period. Descriptive statistics are summarized in Table 2.

Figures for trade value of exports and imports between China and ASEAN presented in U.S. dollars are retrieved from the UNCTAD database, while those on the gross domestic product are obtained from the World Development Indicators and the World Bank. In the literature, partners with a larger volume tend to trade more, thus factors of the gross domestic products are predicted with positive outcomes. Variables of distance and gravity terms are obtained from GeoDist and CEPII, and are expected to turn out traditional results. Trading multilateral resistance variables are inserted in the model to augment the adequacy of estimation; in addition, these variables expectedly reduce unobserved problems. Data on multilateral resistances are taken from official websites of regional and international organizations and official websites of interested governments.

\subsection{Estimated Results}

First, we estimate gravity equation system with both Random effects approach and PPML approach for aggregate trade and its components of exports and imports. The results are reported in Table 3. The outcomes for Ramsey test shown in the second to last row confirm that the PPML estimator is more appropriate. In addition, results with PPML technique are seemingly more significant than those with the Random effects estimator (higher S-square and more statistically significant coefficients). 
Table 3: Estimated Results under Random effects and PPML

\begin{tabular}{|c|c|c|c|c|c|c|}
\hline \multirow{2}{*}{ Variable } & \multicolumn{3}{|c|}{ Random Effects } & \multicolumn{3}{|c|}{ PPML } \\
\hline & Intrade & Inexport & Inimport & trade & export & import \\
\hline Ingdpi & $18.77^{\mathrm{b}}$ & $15.84^{c}$ & $21.99^{a}$ & $6.70^{\mathrm{b}}$ & $5.59^{a}$ & $8.05^{c}$ \\
\hline Ingdpj & 0.58 & 0.17 & 0.71 & 0.02 & 0.06 & -0.03 \\
\hline Inincomei & -18.88 & -15.44 & -22.61 & -6.09 & -4.87 & -7.57 \\
\hline Inincomej & 0.0 & $0.05^{b}$ & 0.44 & $0.26^{b}$ & $0.19^{a}$ & $0.36^{c}$ \\
\hline Indistance & $-6.10^{c}$ & $-5.14^{b}$ & $-8.84^{c}$ & $-2.98^{b}$ & $-2.53^{c}$ & $-3.79^{a}$ \\
\hline language & 1.16 & 1.42 & 1.15 & $0.93^{c}$ & $0.72^{b}$ & $1.27^{c}$ \\
\hline landlocked & -3.63 & -4.43 & -3.97 & $-3.96^{a}$ & $-4.11^{c}$ & $-3.86^{c}$ \\
\hline border & -0.43 & -0.21 & -0.74 & $0.03^{b}$ & $0.11^{b}$ & -0.13 \\
\hline obor & -0.07 & 0.01 & -0.11 & $-0.11^{a}$ & $-0.03^{a}$ & -0.22 \\
\hline wto & $0.36^{c}$ & $0.39^{c}$ & 0.23 & 0.19 & 0.18 & 0.18 \\
\hline acfta & 0.075 & -0.05 & 0.30 & -0.09 & -0.15 & -0.02 \\
\hline _cons & 49.5 & 40.08 & $70.23^{a}$ & $24.14^{b}$ & $19.85^{\circ}$ & $29.70^{c}$ \\
\hline fixed effect & yes & yes & yes & yes & yes & yes \\
\hline R-square & 0.54 & 0.55 & 0.49 & 0.59 & 0.59 & 0.62 \\
\hline $\mathrm{N}$ & 190 & 190 & 190 & 190 & 190 & 190 \\
\hline Ramsey test & 0.0000 & 0.0000 & 0.0000 & 0.1126 & 0.0962 & 0.1254 \\
\hline
\end{tabular}

legend: ${ }^{a}: p<0.05 ;{ }^{b}: p<0.01 ;{ }^{c}: p<0.001$

It is a well-known fact that the economic scale of China is one of the most crucial factors influencing both aggregate trade and separate elements of imports and exports. It is rationally understandable that with a huge economy and a rapid economic development, China is able to export more to ASEAN. With the same reason, China also needs to import more from ASEAN members. The estimated results for traditional gravity dummy variables mostly turn out with expected signs in which common language and sharing border (excepting for import) enhance bilateral trade, while a landlocked country is likely to deter trading activities between two parties. The estimated coefficients for wto and acfta are statistically insignificant, suggesting that joining the WTO and participating in the ACFTA seemingly do not contribute to trade flows. These results strongly support a recent argument that traditional regional-international trade platforms like the WTO, even the ACFTA are faded away in their effects and now the world needs new cooperation mechanisms such multilateral regionalism (Baldwin, 2006; Baldwin and Low, 2009). Finally, estimated coefficients for obor are statistically significant and come up with reversed expectation, implying that recent efforts by China in promoting and fulfilling the BRI has made relatively limited gains. This may come from political concerns of ASEAN states about the hegemonic ambition of China, which might be beyond the purpose of economic cooperation and development (Greiman, 2014; Das, 2018; Gong, 2019).

Next, we produce estimation for sub-sections of trade classified by technology content. The results are reported in Table 4. Obviously, the estimated results for sub-sections of trade flows are partially different from outcomes for aggregate trade and trade components of exports and imports. The economic size of China helpfully contributes to export and import of low technology products to/from ASEAN members since the coefficients are statistically significant, while there is no impact on other sub-sections. The explanation for those results lies in the characteristics and structure of trade between China and ASEAN countries. Looking in detail at trade figures, we can observe that the proportion of low technology products in total bilateral trade was significant. The estimation reveals the advantageous impact of a common language variable on many sub-sectors. On the contrary, physical distance is found to impede all sub-sectors for both export and import sectors. Of note it that getting involved with the BRI led by China predictably enhances export flows of low technology products to its ASEAN partners, but does not influence its imports from those countries. In a broader view, the BRI has seemingly failed to reach its target, but it still gains some relative achievements associated to exports of low technology products. 
Table 4: Estimated Results with Sub-section of Export under PPML

\begin{tabular}{|c|c|c|c|c|c|c|c|c|c|c|c|c|}
\hline \multirow[t]{2}{*}{ Variable } & \multicolumn{2}{|c|}{ primary } & \multicolumn{2}{|c|}{$\begin{array}{l}\text { resource- } \\
\text { based }\end{array}$} & \multicolumn{2}{|c|}{ low technology } & \multicolumn{2}{|c|}{$\begin{array}{l}\text { medium } \\
\text { technology }\end{array}$} & \multicolumn{2}{|c|}{$\begin{array}{c}\text { high } \\
\text { technology }\end{array}$} & \multicolumn{2}{|c|}{ unclassified } \\
\hline & Export & Import & Export & Import & Export & Import & Export & Import & Export & Import & Export & Import \\
\hline Ingdpi & 6.99 & $0.08^{b}$ & 11.14 & -6.39 & $4.86^{\mathrm{b}}$ & $30.71^{a}$ & $-1.01^{b}$ & 10.53 & 7.60 & 13.16 & 41.35 & $60.29^{a}$ \\
\hline Ingdpj & -0.02 & -0.02 & -0.02 & $-0.33^{c}$ & $0.12^{\mathrm{a}}$ & 0.22 & 0.02 & -0.04 & 0.11 & $0.42^{\mathrm{c}}$ & $0.35^{a}$ & 0.32 \\
\hline Inincomei & -6.37 & 1.51 & -10.34 & 7.83 & -3.98 & -31.29 & 2.31 & -10.62 & -7.33 & -13.64 & -42.84 & -62.27 \\
\hline Inincomej & -0.04 & $-0.27^{c}$ & 0.05 & $0.20^{\mathrm{a}}$ & 0.06 & $0.42^{\mathrm{a}}$ & 0.05 & $0.97^{\circ}$ & $0.49^{c}$ & $0.92^{\circ}$ & $0.99^{c}$ & $1.32^{b}$ \\
\hline Indistance & $-3.12^{c}$ & $-2.46^{c}$ & $-2.12^{c}$ & $-5.42^{c}$ & $-1.62^{c}$ & $-1.24^{b}$ & $-2.40^{c}$ & $-7.05^{c}$ & $-3.53^{c}$ & $-4.27^{c}$ & $-2.92^{b}$ & -3.49 \\
\hline language & $0.47^{\mathrm{a}}$ & 0.25 & $0.82^{\mathrm{c}}$ & $1.98^{\circ}$ & 0.34 & 0.38 & $0.66^{b}$ & $1.99^{\circ}$ & $0.93^{\mathrm{c}}$ & $0.91^{\mathrm{c}}$ & $1.54^{\mathrm{c}}$ & 1.96 \\
\hline landlocked & $-5.75^{c}$ & $-3.92^{c}$ & $-5.13^{c}$ & $-3.35^{c}$ & $-3.99^{c}$ & $-5.57^{c}$ & $-3.76^{c}$ & $-5.78^{c}$ & $-4.31^{c}$ & $-8.03^{c}$ & $-2.34^{c}$ & -1.36 \\
\hline border & $-0.54^{b}$ & $-0.71^{b}$ & -0.17 & $-1.4^{c}$ & 0.17 & $1.48^{\mathrm{b}}$ & -0.13 & -0.53 & 0.53 & $1.66^{c}$ & $3.46^{c}$ & $3.21^{\mathrm{b}}$ \\
\hline obor & -0.04 & -0.43 & -0.16 & -0.287 & $0.04^{a}$ & 0.02 & -0.08 & 0.01 & -0.01 & -0.11 & -0.84 & -0.43 \\
\hline wto & -0.22 & $-0.60^{a}$ & $-0.52^{b}$ & 0.04 & 0.10 & 0.64 & -0.20 & 0.27 & $0.96^{c}$ & $1.28^{c}$ & $1.54^{\mathrm{c}}$ & 0.91 \\
\hline acfta & -0.06 & -0.03 & -0.10 & 0.08 & -0.11 & 0.03 & -0.20 & 0.06 & -0.19 & -0.14 & -0.829 & -0.83 \\
\hline cons & $24.96^{c}$ & $18.28^{c}$ & $14.34^{c}$ & $40.21^{b}$ & $10.72^{c}$ & 6.28 & $16.36^{c}$ & $52.17^{c}$ & $26.15^{c}$ & $30.42^{c}$ & $15.9^{\mathrm{a}}$ & 17.06 \\
\hline fixed effect & yes & yes & yes & yes & yes & yes & yes & yes & yes & yes & yes & yes \\
\hline R-square & 0.71 & 0.54 & 0.52 & 0.67 & 0.58 & 0.54 & 0.58 & 0.84 & 0.66 & 0.80 & 0.37 & 0.47 \\
\hline obs & 190 & 190 & 190 & 190 & 190 & 190 & 190 & 190 & 190 & 190 & 190 & 190 \\
\hline $\begin{array}{l}\text { Ramsey } \\
\text { test }\end{array}$ & 0.0638 & 0.2257 & 0.1128 & 0.1987 & 0.3258 & 0.0774 & 0.0821 & 0.1457 & 0.2122 & 0.0788 & 0.1148 & 0.2391 \\
\hline
\end{tabular}

legend: ${ }^{a}: p<0.05 ;{ }^{b}: p<0.01 ;{ }^{c}: p<0.001$

\section{Trade Potentials}

Obviously, there are many approaches, which can be possibly applied to forecast the bilateral trade potential between partners. However, it is accepted that the method of Average Standardized Trade Potential developed by Benedictis and Vicarelli (2005) is widely applied with advantageous strengths. In this paper, we simply follow the style of Benedictis and Vicarelli to predict the trade potentials between China and ASEAN. Then, the index of trade potential is specified as follows:

$$
\text { tradepo }_{i j t}=\sum_{1}^{N} \frac{\frac{\mathrm{obs} / \mathrm{est}-1}{\mathrm{obs} / \mathrm{est}+1}}{N}
$$

where, tradepo is an indicator of bilateral trade potential between China and ASEAN countries; obs denotes observed values of bilateral trade value and separated in export and import, respectively; est presents estimated figures, which are obtained from estimation of gravity equation system (5); and $\mathrm{N}$ is number of sample observation periods. Performance of trade potential index is explained as follows: if tradepo approaches around a value of zero, then it indicates that China and ASEAN countries have been traded well. If, the index of tradepo goes far beyond the critical point positively, it is implied that countries are in a position of being overtraded, otherwise the index goes negatively, then bilateral trade flows are predictably untapped. Trade potential index are presented in Table 5.

It is noticeable that Brunei, Laos and Malaysia have a high possibility to do business with China. Because the figures for trade potential, on the global level and on separate components, show they are untapped, while potential trade with Indonesia is untapped for aggregate trade and import flows, but overtraded for export sector. Remarkably, China is seemingly trading very well with the Philippines, Singapore, Thailand and Vietnam for both import and export flows since those trade potential indexes are nearly reaching the critical value.

We also measure the trade potential between China and ASEAN countries according to technology content. For the sake of saving space, the results are available upon request. The results for trade potentials at sub-sector level show China's export potential is significant with primary subsector and low technology sub-sector. Meanwhile, there is a limited potential for China's exports to ASEAN in the 
Table 5: Scenario of Trade Potential

\begin{tabular}{|l|c|c|c|c|c|c|}
\hline \multirow{2}{*}{ Country } & \multicolumn{2}{|c|}{ Trade } & \multicolumn{2}{c|}{ Export } & \multicolumn{2}{c|}{ Import } \\
\cline { 2 - 7 } & tradepo & scenario & tradepo & scenario & tradepo & scenario \\
\hline Brunei & -0.2102 & untapped & -0.0179 & untapped & -0.0094 & untapped \\
\hline Cambodia & 0.0025 & closed & 0.0026 & closed & 0.0029 & closed \\
\hline Indonesia & -0.0066 & untapped & -0.0066 & overtraded & -0.0097 & untapped \\
\hline Laos & -0.0067 & untapped & -0.3036 & untapped & -0.0332 & untapped \\
\hline Malaysia & -0.0082 & untapped & -0.0068 & untapped & -0.0141 & untapped \\
\hline Myanmar & -0.0009 & closed & -0.0011 & closed & -0.0008 & closed \\
\hline Philippines & -0.0016 & closed & -0.0020 & closed & -0.0011 & closed \\
\hline Singapore & 0.0014 & closed & 0.0021 & closed & 0.0009 & closed \\
\hline Thailand & -0.0007 & closed & -0.0005 & closed & -0.0009 & closed \\
\hline Viet Nam & -0.0008 & closed & -0.0019 & closed & 0.0005 & closed \\
\hline
\end{tabular}

medium and high technology sub-sectors (except Brunei, Malaysia and Vietnam), and resource-based sub-sector (except Brunei and Malaysia). On the other hand, estimated results also illustrate that there is significant room for China's imports from Malaysia, Laos, Indonesia and Brunei in nearly all sub-sectors. On the contrary, China's import potential remains very low in cases of Thailand, Myanmar, Cambodia, Singapore and Philippines (except medium technology subsector and unclassified sub-sector).

\section{Conclusion}

China and ASEAN have long historical trade relations. Looking at the overall picture, both China and ASEAN countries have become mutually vital to each other. One of the principal characteristics of this trade relation is the huge trade deficit of ASEAN. In terms of the nature of trade, China-ASEAN trade had largely focused on products incorporating high technology and medium technology content, which demonstrated the development of production capability in China and ASEAN countries. Estimated results show that, in terms of aggregate trade, China's economic scale has a strong effect on both export and import sectors between China and ASEAN countries. The positive sign for the two regions' trade activities is also found for the variables of common language and sharing border (except import sector). Meanwhile, joining the BRI had a negative influence, implying that there are possibly political concerns from ASEAN countries about China's strategic purposes under this initiative. The paper does not find a positive effect of becoming WTO member and establishing the ACFTA. In terms of technology content, we found that the impacts of elements being considered on sub-sectors are varying, indicating that there is heterogeneity among the parameter estimations in each type of sub-sector. We found that China's economic size has positive effect on low technology subsector for both exports and imports between China and ASEAN countries.

On the other hand, accessing the BRI is only positive for China's low technological exports to ASEAN, showing its modest influence in improving the China-ASEAN trade structure. Computation of trade potential index indicates that there is still room for trade expansion between China and several ASEAN countries, particularly Brunei, Malaysia and Laos, under both aggregate trade and trade by technology content in years to come. This suggests that both sides need to find a new proactive approach if they want to go further, otherwise, they might be limited to the present struggling. Our paper also provides helpful policy recommendations that more efforts should be made to improve mutual political trust between China and ASEAN countries, which in turn will support future trade development of the two regions.

\section{References}

Anderson, J. E., \& Wincoop, E. V. (2003). Gravity with Gravitas: A Solution to the Border Puzzle. American Economic Review, 93(1), 170-192.

Armstrong, S. (2015). East and South Asia: Managing Difficult Bilateral Relations and Regional Integration Globally. Asian Economic Journal, 29(4), 303-324.

Athukorala, P. C. (2011). Production Networks and Trade Patterns in East Asia: Regionalization or Globalization? Asian Economic Papers, 10(1), 65-95.

Baldwin, R. E. (2006). Multilateralising Regionalism: Spaghetti Bowls as Building Blocs on the Path to Global Free Trade. The World Economy, 29(11), 1451-1518.

Baldwin, R. E., \& Low, P. (2009). Multilateralizing regionalism: challenges for the global trading system. Cambridge, UK: Cambridge University Press. 
Benedictis, D. L., \& Vicarelli, C. (2005). Trade Potentials in Gravity Panel Data Models. The B.E. Journal of Economic Analysis \& Policy, 5(1), 1-33.

Balandchard, J. F. (2018). China's Maritime Silk Road Initiative (MSRI) and Southeast Asia: A Chinese 'pond' not 'lake' in the works. Journal of Contemporary China, 27(111), 329-343.

Chakraborty, D., \& Kumar, A. (2012). ASEAN and China: New dimensions in economic engagement. China Report, 48(3), 327-349.

Chen, S. (2018). Regional responses to China's Maritime Silk Road Initiative in Southeast Asia. Journal of Contemporary China, 27(111), 344-361.

Chiang, M. H. (2019). China-ASEAN economic relations after establishment of free trade area. The Pacific Review, 32(3), 267-290.

Chin, G., \& Stubbs, R. (2011). China, regional institutionbuilding and the China-ASEAN Free Trade Area. Review of International Political Economy, 18(3), 277-298.

Cook, M. (2019). Divergence and Displacement: Southeast AsiaChina Trade, 2013-2018. ISEAS Perspective, 88. Singapore: Yusof-Ishak Institute.

Das, S. (2018). Do the economic ties between ASEAN and China affect their strategic partnership? ISEAS Perspective, 32. Singapore: Yusof-Ishak Institute.

Devadason, E. S. (2010). ASEAN-China Trade Flows: moving forward with ACFTA. Journal of Contemporary China, 19(66), 653-674.

Egger, P. (2002). An Econometric View on the Estimation of Gravity Models and the Calculation of Trade Potentials. The World Economy, 25(2), 297-312.

Gaulier, G., Lemoine, F., \& Unal-Kesenci, D. (2007). China's Integration in East Asia: Production Sharing, FDI \& HighTech Trade. Economic Change and Restructuring, 40, 27-63.

Greiman, V. A. (2014). A Model for Collaborative Development in the South China Sea. Journal of Asian Finance, Economics and Business, 1(1), 31-40. https://doi.org/10.13106/jafeb.2014. vol1.no1.31

Gujariti, D.N. (2004). Basic Econometrics (4th Ed.). New York, NY: McGraw-Hill.

Gong, X. (2019). The Belt \& Road Initiative and China's influence in Southeast Asia. The Pacific Review, 32(4), 635-665.

He, Y., \& Wang, J. (2019). A Panel Analysis on the Cross Border E-commerce Trade: Evidence from ASEAN Countries. Journal of Asian Finance, Economics and Business, 6(2), 95-104. https://doi.org/10.13106/jafeb.2019.vol6.no2.95

Hye, Q. M. A., Wizarat, S., \& Lau, W. Y. (2016). The Impact of Trade Openness on Economic Growth in China: An Empirical
Analysis. Journal of Asian Finance, Economics and Business, 3(3), 27-37. https://doi.org/10.13106/jafeb.2016.vol3.no3.27

Ju, J., \& Yu, X. (2018). China's opening up after 40 years: Standing at a historic turning point. China \& World Economy, 26(2), 23-49.

Liqin, W. (2012). Competitive or Complementary?: China's Role in Trade Cooperation with ASEAN in the 1990s and 2000s. China: An International Journal, 10(3), 63-85.

Men, J. (2007). The Construction of the China-ASEAN Free Trade Area: A Study of China's Active Involvement. Global Society, 21(2), 249-268.

Oktora, S. J., \& Firdani, A. M. (2019). Natural Rubber Economics between China and Southeast Asia: The Impact of China's Economic Slowdown. Journal of Asian Finance, Economics and Business, 6(2), 55-62. https://doi.org/10.13106/jafeb.2019. vol6.no2.55.

Rao, T., \& Pathak, R. (2016). China's Ascent in World Trade and Associated Shift in its Trade Structure. Journal of Asian Finance, Economics and Business, 3(3), 39-55. https://doi. org/10.13106/jafeb.2016.vol3.no3.39

Santasombat, Y. (2018). Chinese Capitalism and Economic Integration in Southeast Asia. Trends in Southeast Asia Series, 7, 1-29.

Santos-Silva, J. M. C., \& Tenreyro. S. (2006). The Log of Gravity. The Review of Economics and Statistics, 88(4), 641-658.

Santos Silva, J. M. C., \& Tenreyro. S. (2011). Further Simulation Evidence on the Performance of the Poison Pseudo-maximum Likelihood Estimator. Economics Letters, 112(2), 220-222.

Tai, W. P., \& Soong, J. J. (2014). Trade relations between China and southeast: Asia strategy and challenge. Chinese Economy, 47(3), 23-39.

Tham, S. Y., Kamandrew, J. Y., \& Abdulaziz, N. I. (2016). Moving up the value chain in ICT: ASEAN Trade with China. Journal of Contemporary Asia, 46(4), 680-699.

Tinbergen, J. (1962). Shaping the World Economy: Suggestions for an International Economic Policy. New York, NY: The Twentieth Century Fund.

Truong, H. Q., Dong, C. V., \& Nguyen, H. H. (2019a). Determinants of Trade Flows and Trade Structure between Korea and ASEAN. East Asian Economic Review, 23(1), 55-88.

Truong, H. Q., Dong, C. V., \& Nguyen, H. H. (2019b). TaiwanASEAN Trade Relations: Trade Structure and Trade in Value Added. China Report, 55(2), 102-124.

Wong, J., \& Chan, S. (2003). China-ASEAN free trade agreement: shaping future economic relations. Asian Survey, 43(3), 507-526. 